\title{
Community-based ecotourism: peran 'Pokdarwis' dalam branding Siak Hijau
}

\author{
Toni Hartono ${ }^{1}$, Febby Amelia Trisakti², Ihda Fuadiah ${ }^{3}$ \\ 1,2,3 Universitas Islam Negeri Sultan Syarif Kasim Riau, Pekanbaru, Indonesia
}

\begin{abstract}
ABSTRAK
Pengembangan ekowisata sedang marak dilakukan oleh pemerintah di berbagai wilayah di belahan dunia. Banyak daerah yang kemudian berlomba-lomba untuk menginisiasi program sejenis. Salah satu kabupaten yang mencanangkan Kabupaten Hijau ialah Kabupaten Siak melalui program Siak Hijau. Artikel ini bertujuan untuk mengemukakan konsep community-based ecotourism (CBET) yang diimplementasikan oleh kelompok sadar wisata (pokdarwis) dalam upaya pengembangan Siak Hijau melalui Ekowisata Mangrove. Penelitian ini menggunakan metode deskriptif kualitatif dengan pengumpulan data melalui observasi, wawancara, dan dokumentasi. Hasil penelitian menunjukkan bahwa masyarakat tempatan yang tergabung dalam Pokdarwis menginisiasi adanya ide pengembangan destinasi ekowisata mangrove dengan bentuk kerjasama dari pemerintah daerah dan pihak-pihak swasta. Beberapa destinasi yang menjadi contoh yakni Ekowisata Mangrove Mengkapan, Rawa Mekar Jaya, dan Sungai Rawa. Dalam implementasinya, kelompok sadar wisata (pokdarwis) berperan aktif dalam perencanaan, pelaksanaan hingga pengawasan kawasan destinasi ekowisata tersebut dan dibantu oleh masyarakat sekitar. Pihak-pihak terkait melakukan promosi secara gencar untuk mengundang para wisatawan ke kawasan ekowisata yang terdapat di Kabupaten Siak. Dampak yang dirasakan terlihat dari adanya pelestarian alam dan adanya pemberdayaan ekonomi di sekitar kawasan ekowisata seperti halnya prinsip yang terdapat dalam ekowisata berbasis komunitas (CBET). Upaya pengembangan ekowisata mangrove juga dimaksudkan untuk mengangkat nama daerah dalam upaya mencapai Siak Hijau yang akan memberikan kontribusi bagi pelestarian lingkungan guna menghasilkan oksigen yang lebih baik bagi dunia.
\end{abstract}

Kata-kata Kunci: Community-based; ekowisata; pokdarwis; Siak Hijau; mangrove

\section{Community-based ecotourism: The role of 'Pokdarwis' in Siak Hijau branding}

\section{ABSTRACT}

Governments are generating ecotourism development in various regions of the world. Many regions are then competing to initiate similar programs. One of the districts that launched the Green District is Siak Regency through the Green Siak program. This article aims to put forward the concept of community-based ecotourism (CBET) implemented by tourism awareness groups (Pokdarwis) to develop Siak Hijau through Mangrove Ecotourism. This study uses descriptive qualitative methods, and the data is collected through observation, interviews, and documentation. The results showed that the local people who are members of Pokdarwis initiated the idea of developing a mangrove ecotourism destination in the form of cooperation from the local government and private parties. Some of the destinations that become examples are Mangrove Ecotourism of Mengkapan, Rawa Mekar Jaya, and Rawa River. In its implementation, the tourism awareness group (Pokdarwis) plays an active role in the planning, implementing, and supervising of the ecotourism destination area and is assisted by the surrounding community. The relevant parties conducted an intensive promotion to invite tourists to the ecotourism area in Siak Regency. The perceived impact can be seen from the nature conservation and economic empowerment around the ecotourism area and the principles contained in CBET. Mangrove ecotourism development efforts are also intended to raise the region's name to achieve Siak Hijau (Green Siak), which contributes to environmental preservation to produce better oxygen for the world.

Keywords: Community-based; ecotourism; pokdarwis; Siak Hijau; mangrove

Korespondensi: Dr. Toni Hartono, M.Si. Universitas Islam Negeri Sultan Syarif Kasim Riau. Jalan HR. Soebrantas Panam Km. 15 No. 155.28293.Email: toni.hartono@uin-suska.ac.id 


\section{PENDAHULUAN}

Konsep "Kota Hijau" atau "Kabupaten Hijau" telah lama menjadi perhatian pihak manapun baik pemerintah maupun akademisi. Salah satu tolok ukur pengaplikasian konsep Kota Hijau adalah keberadaan Ruang Terbuka Hijau (RTH) di perkotaan. Ruang Terbuka Hijau pada suatu kota harus memenuhi luasan minimal yakni sebesar 30\% dari keseluruhan luas lahan dengan komposisi 20\% ruang terbuka hijau publik dan $10 \%$ ruang terbuka hijau privat (Undang-Undang No. 26 Tahun 2007). Para akademisi juga menjadikan isu ini sebagai diskursus penting, seperti penelitian Alfini Baharuddin (Baharudin, 2011) dan Syamsul Rijal (Rijal, 2008). Keduanya menyebutkan bahwa di Kota Jayapura dan Makassar membutuhkan RTH yang sebanding dengan jumlah penduduk.

Berdasarkan amanat dalam Undangundang dan pentingnya RTH dalam memenuhi kebutuhan dasar hidup manusia, maka seluruh daerah perlu bergegas untuk mewujudkannya.

Salah satu daerah yang memiliki komitmen tinggi terhadap konsep "Kabupaten Hijau" adalah Siak. Bahkan, pada tahun 2017, pemerintah Kabupaten Siak mendapatkan penghargaan dari Kementerian Lingkungan Hidup dan Kehutanan (Kemen LHK) sebagai Green City dan satu-satunya kabupaten di
Indonesia yang meraih penghargaan tersebut.

Siak Hijau muncul dari kesadaran pemerintah bersama masyarakat untuk menjaga lingkungan pasca kebakaran hutan dan lahan (Karhutla) pada tahun 2014-2015 (siakkab. go.id, 2019). Di samping itu, penyelesaian permasalahan perambahan hutan, pembalakan liar, kebakaran, dan illegal land tenure juga terus dilakukan. Sebagai payung hukumnya, maka dikeluarkan Peraturan Bupati Nomor 22 tahun 2018 yang memuat zonasi, strategi, arah kebijakan, dan indikator menuju Siak Hijau.

Upaya dan strategi telah dilakukan secara masif dan berkelanjutan untuk mewujudkan Siak Hijau. Hal ini juga ditandai dengan perubahan status kawasan hutan suaka menjadi taman nasional. Bahkan jumlah areal kawasan hutan dari 28.000 Ha menjadi 31.000 Ha yang sudah ditetapkan oleh Kemen LHK. Selain itu, kawasan pinggiran sungai yang terdapat kawasan mangrove terus dijaga dan dilestarikan dengan melibatkan masyarakat di kawasan dan dijadikan ekowisata (Siak \& Siak, 2019).

Kawasan hutan mangrove diartikan sebagai hutan yang tumbuh di daerah pasang surut, terutama di pantai yang terlindung, laguna dan muara sungai yang tergenang pada saat pasang dan bebas dari genangan pada saat surut yang komunitas tumbuhannya bertoleransi terhadap garam. (Kementerian Perikanan dan Kelautan, 2019). Istilah mangrove merupakan 
kombinasi dua bahasa, mangue dan grove. Kata mangrove dalam bahasa Inggris digunakan untuk komunitas tumbuhan yang tumbuh di daerah jangkauan pasang surut maupun untuk individu-individu jenis tumbuhan yang menyusun komunitas tersebut. Hutan mangrove juga dikenal dengan istilah tidal forest, coastal woodland, vloedbosschen dan hutan payau (bahasa Indonesia) (Annesva, 2016).

Sejumlah fakta penting saat ini yang dimiliki kabupaten Siak untuk mendukung Green City adalah RTH dengan luas 11.234 Ha. RTH seluas itu tersebar di beberapa wilayah yaitu, Taman Tengku Syarifah Aminah seluas 17.005 $\mathrm{M}^{2}$, Taman Kota Sultan Yahya dengan luas $16.621 \mathrm{M}^{2}$, Taman Tengku Maharatu seluas $1.827 \mathrm{M}^{2}$, Hutan Kota Arwinas dengan luas 33 Ha., Taman Tengku Agung seluas 279,51 M², Taman Syekh Abdurrahman dengan luas 16.196 $\mathrm{M}^{2}$, dan Ekowisata Mangrove yang tersebar pada beberapa wilayah di Kabupaten Siak (Pesona Siak - The Official Guide of Siak Regency, 2019).

Ekowisata mangrove atau bakau ini merupakan bagian penting untuk mendukung status Green City. Saat ini, Siak memiliki tiga destinasi ekowisata mangrove yaitu Ekowisata Mangrove Rawa Mekar Jaya, Ekowisata Mangrove Mengkapan, dan Ekowisata Mangrove Sungai Rawa. Ketiganya merupakan bentuk upaya yang dilakukan untuk memperluas wilayah Hijau di Kabupaten Siak. Hadirnya kawasan wisata mangrove tersebut salah satu bukti komitmen Pemerintah Kabupaten Siak bersama-sama dengan lapisan masyarakat menjadi Kabupaten Hijau. Hal ini juga dikemukakan oleh Humas Kabupaten Siak saat wawancara yakni selain dijadikan sebagai tempat wisata, ekowisata hutan mangrove ini dikembangkanuntuk pelestarian hutan, menjaga keseimbangan alam, mencegah pembalakan liar dan juga warisan untuk generasi penerus. Sehingga dengan tetap dijaga dan dilestarikan maka ekowisata hutan mangrove ini akan memberikan banyak manfaat untuk generasi penerus dan menstabilkan ekosistem alam.

Sebagai salah satu bentuk ekowisata yang berguna dalam pelestarian alam, mangrove sangat potensial bagi 24 pengembangan ekowisata karena kondisi mangrove yang sangat unik serta model wilayah yang dapat dikembangkan sebagai sarana wisata dengan tetap menjaga keaslian hutan serta organisme yang hidup di kawasan mangrove. Pemanfaatan kawasan mangrove untuk dikembangkan menjadi salah satu kawasan ekowisata merupakan alternatif pemanfaatan yang sangat rasional diterapkan di kawasan pesisir karena dapat memberi manfaat ekonomis dan jasa lingkungan tanpa mengeksploitasi mangrove. Bahkan, pemanfaatan ekowisata mangrove akan mendorong upaya konservasi ekosistem 
sebagai daerah penyangga kawasan konservasi (Karlina, 2015).

Melalui pengembangan ekowisata mangrove tersebut, pemerintah kabupaten Siak melakukan inovasi baru agar Siak semakin maju dan dikenal sebagai Green City serta menjadi destinasi wisata yang diperhitungkan di tingkat lokal, nasional, dan internasional. Salah satu destinasi ekowisata yang dikembangkan adalah wisata alam terutama hutan mangrove, yang memiliki luas sekitar 6.820,53 hektar (Pesona Siak - The Official Guide of Siak Regency, 2019).

Istilah ekowisata dalam konteks penelitian ini mengacu pada perjalanan wisata ke suatu tempat atau lingkungan baik alam yang alami maupun buatan, serta kebudayaan yang bersifat inovatif dan partisipatif dengan tujuan untuk menjamin kelestarian alam, sosial, dan budaya. Lebih lanjut, penelitian ini membahas mengenai istilah community-based tourism atau yang biasa disebut dengan ekowisata berbasis masyarakat yang membawa dimensi sosial ini selangkah lebih maju. Konsep ini menjelaskan bentuk ekowisata di mana masyarakat lokal memiliki kontrol substansial atas, dan keterlibatan dalam, pengembangan dan pengelolaannya, dan sebagian besar manfaat tetap dalam masyarakat. Aset alam suatu negara, yang dikelola dengan baik, memberikan sumber nilai emosional dan simbolis yang kuat untuk audiens internal dan eksternal (Insch, 2011).

Ekowisata saat ini menjadi salah satu pilihan dalam mempromosikan lingkungan yang khas terjaga keasliannya sekaligus menjadi suatu kawasan kunjungan wisata. Potensi ekowisata adalah suatu konsep pengembangan lingkungan yang berbasis pada pendekatan pemeliharaan dan konservasi alam. Dengan demikian ekowisata sangat tepat diberdayagunakan dalam mempertahan-kan keutuhan dan keaslian ekosistem di area yang masih alami. Salah satu bentuk ekowisata yang dapat melestarikan lingkungan alam dengan ekowisata adalah mangrove.

Konsep ekowisata menyatukan konservasi, komunitas, dan perjalanan berkelanjutan. Hal ini berarti bahwa pihak terlibat dalam menerapkan dan berpartisipasi untuk memasarkan kegiatan ekowisata harus mengadopsi prinsip-prinsip ekowisata berikut: (1) Meminimalkan dampak fisik, sosial, perilaku, dan psikologis; (2) Membangun kesadaran dan penghargaan lingkungan dan budaya; (3) Memberikan pengalaman positif bagi pengunjung dan tuan rumah; (4) Memberikan manfaat finansial langsung untuk konservasi; (5) Menghasilkan manfaat finansial bagi masyarakat lokal dan industri swasta; (6) Memberikan pengalaman interpretatif yang mengesankan kepada pengunjung yang membantu meningkatkan sensitivitas terhadap iklim politik, lingkungan, 
dan sosial negara tuan rumah; (7) Merancang, membangun dan mengoperasikan fasilitas berdampak rendah; dan (8) Kenali hak-hak dan keyakinan spiritual Penduduk Asli di komunitas Anda dan bekerja dalam kemitraan dengan mereka untuk menciptakan pemberdayaan ("What Is Ecotourism," 2018).

Dari ketiga kawasan ekowisata yang ada di kabupaten Siak, Ekowisata Mangrove Mengkapan adalah wisata alam hutan mangrove pertama yang ada di Siak. Destinasi ini sudah ada sejak tahun 2004, namun baru mulai terekspos pada tahun 2015. Berkat kegigihan masyarakat dan beberapa pihak yang membantu, saat ini kawasan ekowisata mangrove Mengkapan menjadi salah satu destinasi wisata yang cukup berpotensi (Zul, 2017).

Kajian mengenai destinasi ekowisata menjelaskan Indeks Nilai Penting (INP) mangrove menunjukkan peran penting mangrove untuk Pulau Balai kota Bengkulu tergolong sedang untuk tingkat pohon berkisar antara 105,42-150,11 (Febriansyah et al., 2018). Ekosistem mangrove dalam kajian lainnya terdapat di Kecamatan Ujung Pangkah, Kabupaten Gresik dan memiliki peran yang penting dalam kehidupan manusia, flora, dan fauna di delta Sungai Bengawan Solo. Keberadaan ekosistem mangrove tersebut terancam oleh polusi dari tumpahan minyak, baik dari aktivitas industri di daratan, maupun di perairan. Hasil penelitian menunjukkan terdapat sekitar $8,16 \%$ dari total luas kawasan di Kecamatan Ujung Pangkah yang masuk ke dalam kategori sangat peka, dan terletak secara dominan pada daerah mudflat yang digunakan sebagai lahan tambak. Tingkat kepekaan didominasi oleh katagori peka (82,67\%), terletak di daratan seluas $5.919,61$ ha dan di lautan seluas 4.765,68 ha (Prasetyo dkk., 2017).

Sebuah studi seperti pariwisata berbasis masyarakat atau community based tourism (CBT) dapat meningkatkan ekonomi pedesaan (Goodwin \& Santilli, 2009) dan (Harwood, 2010). Dalam kebanyakan kasus, ekowisata didorong oleh kepemilikan asing atau sektor swasta yang tidak berkontribusi banyak bagi masyarakat itu sendiri. Keterlibatan masyarakat hanya dibahas dalam istilah-istilah yang dangkal tetapi tujuan utamanya adalah untuk mendapat untung dari entitas komersial tersebut. Memang, hal itu menyebabkan perpindahan, peningkatan biaya, kebocoran ekonomi, hilangnya akses ke sumber daya, dan gangguan sosial budaya di antara penduduk setempat.

Pengembangan pariwisata berkelanjutan dikemukakan dalam (Yaman \& Mohd, 2004) harus terdapat empat syarat yang harus dipenuhi; (1) anggota masyarakat setempat harus berpartisipasi dalam proses perencanaan dan pengembangan; (2) pendidikan populasi tuan rumah, pengembangan industri dan pengunjung 
harus terjadi; (3) kualitas habitat satwa liar, penggunaan energi dan iklim mikro harus dipahami dan dihormati; dan (4) investasi moda transportasi alternatif. Manfaat ekonomi akan diperoleh komunitas lokal ketika kepemilikan lokal dan partisipasinya berada pada level yang signifikan. Kepemilikan lokal yang lebih tinggi dan keterlibatan wirausaha akan memberikan rasa stabilitas ekonomi yang lebih besar dan perasaan tidak diabaikan oleh usaha.

Karena sifatnya, ekowisata berbasis komunitas membawa para konsumen ke produk itu sendiri, memberikan peluang besar untuk membangun kontak dan hubungan. Melalui kontak dengan para wisatawan, para anggota belajar berbagai pengetahuan dan pengalaman baru, yang sangat mustahil tanpa kegiatan pariwisata. Anggota masyarakat dengan kemampuan kewirausahaan dapat menjalin kontak bisnis melalui operator tur, agen, atau turis sendiri untuk memulai bisnis baru.

Pengembangan ekowisata mangrove penting dilakukan untuk menguatkan label Siak Hijau yang disematkan oleh pemerintah pusat. Ekowisata mangrove bagi pemerintah daerah Siak menjadi bagian penting dari Green City. Oleh karena itu, artikel ini bertujuan untuk mengulas lebih detil mengenai bagaimana pengembangan ekowisata Mangrove diimplementasikan dari aspek peran kelompok sadar wisata (Pokdarwis) dalam upaya mengembangkan destinasi ekowisata berbasis masyarakat.

\section{METODE PENELITIAN}

Dalam penelitian ini, penulis menggunakan pendekatan kualitatif atau yang biasa disebut metode naturalistik (natural setting) (Creswell, 2007). Penelitian kualitatif dapat digunakan untuk meningkatkan desain dan interpretasi survei tradisional. Ini mengeksplorasi fenomena yang belum diteliti sebelumnya.

Penelitian kualitatif digunakan untuk memahami fenomena sosial apa pun dari perspektif aktor yang terlibat, bukan menjelaskannya dari luar (Mohajan, 2018). Penulis kemudian memilih metode deskriptif dalam melakukan penelitian ini, seperti halnya yang dijelaskan oleh (Punch, 2013) yakni deskriptif kualitatif adalah jenis penelitian ilmu sosial yang mengumpulkan dan bekerja dengan data non-numerik yang berupaya menafsirkan makna dari data ini yang membantu kita untuk memahami kehidupan sosial melalui studi populasi atau tempat yang ditargetkan.

Penelitian dilakukan pada bulan AgustusNovember 2019 di Kabupaten Siak, dengan mengumpulkan para informan yang menjadi subjek penelitian yakni pihak-pihak yang terlibat dalam program Siak Hijau, mulai dari pemerintah kabupaten Siak, para kelompok sadar wisata (pokdarwis), satuan kerja perangkat 
daerah terkait, seperti Dinas Pariwisata, dan masyarakat Kabupaten Siak. Sedangkan objek dalam penelitian ini ialah komponen penentu dalam pengembangan Siak Hijau, mulai dari peran pokdarwis hingga program konkret yang dilaksanakan oleh Kabupaten Siak. Data didapat melalui observasi dan wawancara mendalam, serta pengumpulan berbagai studi pustaka. Lebih lanjut, penulis menganalisis data yang dikumpulkan melalui analisis data kualitatif sehingga menghasilkan hasil penelitian yang dinarasikan dalam bentuk esai.

Data yang telah dikumpulkan penulis kemudian dianalisis menggunakan analisis data kualitatif, yang terdiri dari beberapa tahapan yakni: (1) Kategorisasi data; (2) Identifikasi tema, pola, dan hubungan. Tidak seperti metode kuantitatif, dalam analisis data kualitatif, tidak ada teknik yang dapat diterapkan secara universal yang dapat diterapkan untuk menghasilkan temuan; dan (3) Meringkas data (Dudovskiy \& John, 2015). Dalam penelitian ini, penulis menyajikan data yang telah disimpulkan melalui proses analisis data. Penulis menyajikan berbagai data yang dikumpulkan melalui transkrip wawancara, observasi langsung serta sinkronisasi data yang didapat melalui sumber sekunder.

\section{HASIL DAN PEMBAHASAN}

Pengembangan ekowisata mangrove di kunci, Aris Dharma selaku perwakilan dari

Kabupaten Siak salah satu idenya berasal dari masyarakat tempatan, yakni komunitas atau kelompok masyarakat pecinta alam dan peduli lingkungan yang juga bertempat tinggal di sekitar kawasan ekowisata. Komunitas tersebut membentuk kelompok sadar wisata (Pokdarwis) dan mendapat pengakuan dari pemerintah Siak melalui penerbitan Surat Keputusan dari Kepala Desa Rawa Mekar Jaya. Hal tersebut menjadi bukti kepastian hukum agar pengembangan hutan mangrove dapat berjalan secara sistematis dan sesuai aturan yang ada.

Bermula hanya sebagai tempat untuk melangsirkan bibit mangrove, kemudian pada tahun 2016, kawasan ekowisata di Kabupaten Siak kemudian berkembang setelah mendapatkan SK sebagai salah satu destinasi wisata di Siak, dan juga menjadi salah satu ikon kabupaten hijau, yaitu ekowisata hutan mangrove. Tepat pada tanggal 8 Oktober 2016, kawasan destinasi ekowisata mangrove resmi dibuka di Kabupaten Siak. Salah satunya ialah Ekowisata Rawa Mekar Jaya, seperti pada gambar 1.

Kegiatan pengembangan hutan mangrove tersebut tidak hanya dikerjakan oleh masyarakat setempat saja, tetapi juga adanya kerjasama dari perusahaan-perusahaan yang ada di desa dan masyarakat yayasan lintas pesisir. Hal ini juga diperjelas dengan pernyataan dari informan Community-based ecotourism: peran 'Pokdarwis' dalam branding Siak Hijau (Toni Hartono, Febby Amelia Trisakti, Ihda Fuadiah) 


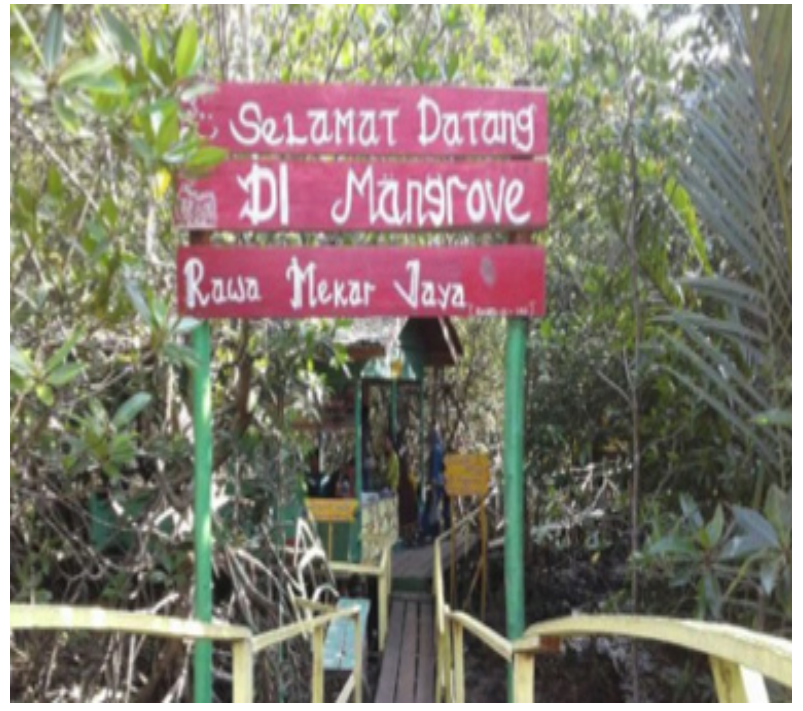

Sumber: Hasil Penelitian, 2019

\section{Gambar 1 Destinasi Ekowisata Mangrove Rawa Mekar Jaya di Kabupaten Siak}

Humas Pemerintah Kabupaten Siak.

"Yang memberikan ide untuk pengembangan hutan mangrove dan menjadikannya ekowisata adalah dari masyarakat yang peduli lingkungan dan sadar wisata atau biasa disebut Pokdarwis, untuk tetap melestarikan hutan mangrove agar tidak punah dengan menjadikannya tempat wisata. Karena itu masyarakat membuat proposal kerjasama dengan perusahaan yang ada di sekitar desa dan dengan mayarakat yayasan lintas pesisir. (Wawancara, 28 Agustus 2019)

Masyarakat yang bertempat tinggal di daerah konservasi menginisiasi hadirnya ekowisata atas dasar kepedulian terhadap lingkungan dan adanya potensi di desanya untuk dijadikan objek wisata, khususnya hutan mangrove. Hubungan kerjasama yang dibangun antara masyarakat dan pihak-pihak terkait seperti perusahaan-perusahaan di sekitar desa merupakan langkah awal dari implementasi ide masyarakat, bentuk kerjasama dapat berupa sumbangan ide maupun bantuan finansial dengan upaya-upaya pengembangan akses menuju lokasi ekowisata. Kondisi lokasi yang masih tidak mumpuni, jarak yang jauh dari lokasi perkotaan, serta aksesibilitas menjadi alasan penting bagi masyarakat untuk mencari bantuan kepada pemerintah daerah, organisasi non pemerintahan serta pihak-pihak swasta.

Hal ini juga diperkuat oleh pernyataan dari Eka Susanti selaku Seksi Pengelolaan Daya Tarik Wisata dan Penetapan Tandu Daftar Usaha yang menekankan bahwa peran satuan perangkat kerja daerah dalam hal ini menjadi fasilitator, dimana masyarakat membutuhkan informasi untuk berkoordinasi dengan pemerintah daerah ataupun hal terkait regulasi daerah. Hal ini dijelaskan oleh Setiono, selaku perwakilan masyarakat pengelola hutan mangrove yang menyatakan:

"Alhamdulillah untuk ide saya dan temanteman yang membentuk. Hutan mangrove pada mulanya bukan untuk tempat wisata, tapi untuk observasi dan penanaman hutan gundul. Tetapi sekarang alhamdulillah sudah menjadi tempat wisata di Siak, dan yang memberikan ide untuk dijadikan tempat wisata adalah saya dan kelompok masyarakat disini."'(Wawancara, 21 September 2019)

Dalam implementasi destinasi ekowisata diperlukan dukungan dari berbagai pihak untuk menjalankan ide masyarakat pengelola hutan, termasuk didalamnya yakni respon 
dari masyarakat yang tidak tergabung dengan anggota kelompok pengelola untuk memastikan apakah ada pro dan kontra dengan masyarakat sekitar, sebagaimana yang dijelaskan oleh Setiono:

"Respon masyarakat baik dengan dijadikanya hutan mangrove sebagai destinasi ekowisata. Karena masyarakat bisa berjualan di sekitar tempat wisata hutan mangrove, ataupun menyediakan tempat parkir. Mereka bisa mengubah perekonomian mereka. Masyarakat pun secara tidak sengaja turut membantu dalam hal mempromosikan ekowisata mangrove. Karena setiap mereka datang kasana pasti meng-uploadnya ke media sosial, dan itu berdampak bagi publik untuk mengunjungi ekowisata hutan mangrove juga." (Wawancara, 21 September 2019)

Pada awalnya, memang terdapat kontra dikarenakan aktivitas masyarakat sekitar yang masih memanfaatkan hasil hutan berupa kayu yang kontradiktif dengan tujuan Pokdarwis untuk mencegah pembalakan liar atau illegal logging, serta mengurangi adanya penebangan pohon secara liar pula. Kemudian, para kelompok sadar wisata yang menjadi masyarakat pengelola tersebut memberikan pengertian dan pengetahuan tentang bagaimana melakukan pemilihan jenis kayu dalam penebangan pohon untuk kebutuhan masyarakat. Setelah mendapat dampak langsung dari pemanfaatan hutan mangrove sebagai destinasi wisata, barulah masyarakat mendukung penuh dengan melihat adanya kebermanfaatan ekonomi bagi kehidupan masyarakat dengan mulai membuat karya-karya yang kreatif seperti souvenir.

Pemerintah selaku fasilitator, pembina, dan pengawas selalu memperhatikan cara kerja Pokdarwis dan sering mengikut sertakan mereka pelatihan dan diklat tentang pariwisata, agar wawasan mereka tentang pariwisata lebih banyak dan semakin kreatif untuk mengembangkan ekowisata hutan mangrove. Pemerintah juga memberikan penghargaan sebagai apresiasi untuk mereka yang aktif dan giat sehingga bisa motivasi mereka untuk bekerja labih baik lagi kedepannya.

Sejalan dengan yang dijelaskan oleh (Fiorello \& Bo, 2012), Community-based ecotourism (CBET) memberikan pemberdayaan ekonomi karena menawarkan peluang kerja dan manfaat diberikan kepada masyarakat secara adil. Kasus-kasus yang dikemukakan tersebut juga menunjukkan bahwa CBET menyediakan pemberdayaan psikologis karena memungkinkan masyarakat untuk menjadi otonom, untuk mempromosikan budaya mereka, dan untuk berbagi tradisi mereka. Karenanya, mereka mendapatkan kebanggaan dari pengalaman yang mereka miliki.

Ekowisata berbasis masyarakat atau CBET juga dijelaskan memiliki fokus pada perjalanan ke daerah-daerah dengan wisata alam (dibandingkan daerah perkotaan) dan menciptakan hubungan tiga arah yang saling menguntungkan antara konservasianis, 


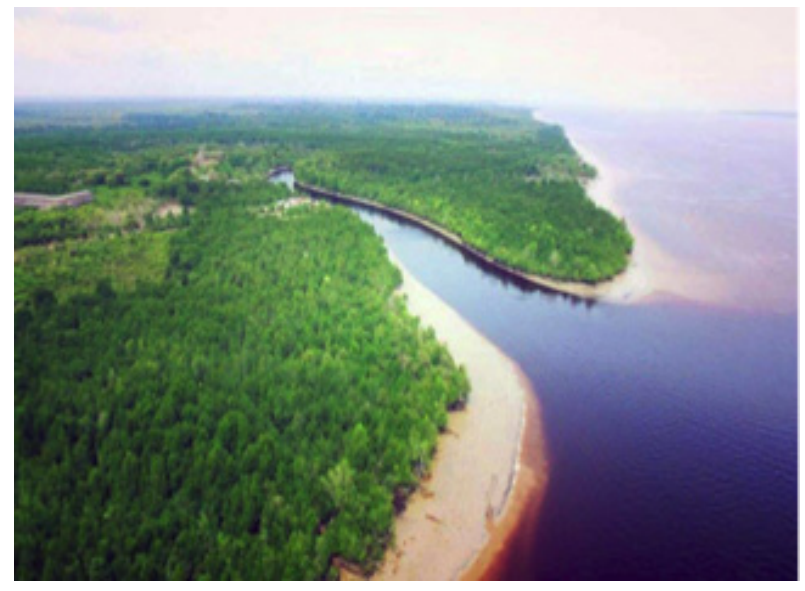

Sumber: Website Pesona Siak, 2019

Gambar 2 Hutan Mangrove di Kabupaten Siak

wisatawan, dan masyarakat lokal (Manu et al., 2012). Nilai tambah yang diperoleh dapat menjadi inovasi lebih lanjut jika potensi destinasi ekowisata didukung oleh penggunaan ilmu pengetahuan dan teknologi informasi yang relevan untuk meningkatkan produktivitas (Purbaningrum, 2018).

Implementasi CBET dalam upaya pengembangan Siak Hijau dengan fokus destinasi ekowisata hutan mangrove dari Pemerintah Kabupaten Siak memiliki potensi yang baik terutama dalam bidang pariwisata dan kelestarian hutan. Manfaat yang didapat dari pengembangan hutan mangrove ialah sebagai pencegahan agar tidak terjadinya abrasi, dengan adanya hutan mangrove dapat menahan pengikisan tanah yang disebabkan oleh air sungai atau laut, seperti pada gambar 2 .

Keseriusan pemerintah kabupaten Siak dinyatakan oleh Aris dalam wawancaranya yang menyebutkan bahwa pengembangan ekowisata hutan mangrove termasuk dalam visi pemda Siak pada bidang pariwisata. Kabupaten Siak juga tergabung dalam Lingkar Temu Kabupaten Lestari, sebuah forum kolaborasi kabupaten untuk mewujudkan pembangunan berkelanjutan di Indonesia. Program "Siak Hijau" juga telah diluncurkan oleh pemerintah kabupaten Siak sebagai suatu kebijakan atau peraturan yang menjadi pedoman bagi pemerintahan, swasta, Civil Society Organization (CSO) dan masyarakat untuk melakukan pengelolaan lingkungan yang sustainable atau berkelanjutan dalam rangka berkontribusi untuk meningkatkan kesejahteraan dan perubahan iklim (Widana, 2019)

Selain memiliki inisiatif dalam pengelolaan lingkungan, pengembangan Siak Hijau dan proses pengambilan keputusan multi pihak Prinsip ini mengacu pada model operasional sinergis dengan pendekatan kemitraan pemerintah-swasta-masyarakat (PublicPrivate-Community Partnership-PPCP) untuk mencapai pembangunan secara berkelanjutan dimana tiga pihak secara bersama-sama mengembangkan unit usaha atau layanan yang saling menguntungkan dan memberikan manfaat sebesar-besarnya bagi masyarakat luas.

Salah satuwujudnyataadanyadukungandari masyarakat lokal ialah melalui pengembangan kawasan destinasi ekowisata mangrove. Setiono 
menyampaikan dalam wawancaranya, landasan masyarakat menyiapkan lokasi ekowisata sebagai berikut:

"Tujuan pertama karena sejarah desa disini hanya dipandang sebelah mata karena jauh dan terpencil serta desa yang tertinggal atau tidak dikenal orang, sehingga tidak ada tujuan apabila datang ke desa ini. Kami selaku pengamat lingkungan memikirkan kalau ada potensi disini contoh adanya hutan mangrove di pesisir sungai. Kemudian kami bertujuan unuk mengangkat nama desa ini dengan mengembangkan dan melestarikan hutan mangrove dan menjadikannya tempat wisata. Jadi dengan adanya tempat wisata orang bisa berkunjung ke desa ini. Tujuan lainnya juga untuk menjaga ekosistem agar tetap stabil." (Wawancara, 21 September 2019)

Siak sebagai kabupaten hijau telah memberikan berbagai macam ide untuk pemerintah maupun masyarakatnya untuk mengembangkan lebih banyak lagi destinasidestinasi wisata khususnya untuk daerah Siak sendiri. Data yang disampaikan oleh Pokdarwis yakni luas hutan mangrove di desadesa kawasan ekowisata terdapat \pm 50 hektar, termasuk trek jalan wisata yang hampir masuk ke dalam hutan. Setiono menjelaskan bahwa dengan pengelolaan yang baik terhadap hutan mangrove, diperkirakan dalam dua sampai tiga tahun kedepan dinilai bagus, dikarenakan kondisi pohon bakau yang besar-besar dan berseni bentuk akarnya, sehingga dapat dimanfaatkan untuk dijadikan rumah pohon sebagai tempat istirahat pengunjung dan menjadi daya tarik wisata. Seperti halnya dalam

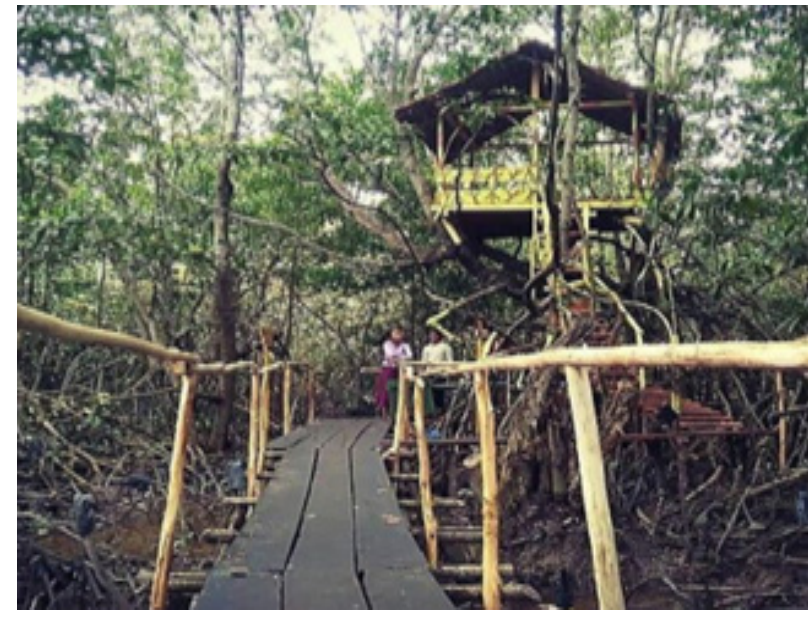

Sumber: Hasil Penelitian, 2019

\section{Gambar 3 Destinasi Ekowisata Mangrove di Kabupaten Siak}

gambar 3, dimana terdapat rumah pohon yang dibangun oleh para Pokdarwis.

Dalam proses perencanaan, Pokdarwis kemudian mengumpulkan orang-orang yang peduli terhadap lingkungan untuk memberikan sosialisasi kepada masyarakat lokal untuk tidak menebang pohon yang ada dalam kawasan hutan mangrove secara liar. Pokdarwis juga memberikan opsi usaha yang potensial dan dapat dilakukan oleh masyarakat lokal. Seperti kutipan dalam wawancara dengan Setiono:

"Upaya yang kami lakukan salah satunya untuk meningkatkan perekonomian masyarakat dan meminimalisir pengangguran serta kemiskinan. Karena jika sebuah tempat wisata ramai dikunjungi, maka mereka pasti membutuhkan jajanan, makanan, minuman, dan lain sebagainya, yang menguntungkan masyarakat untuk berjualan disekitar tempat wisata." (Wawancara, 21 September 2019)

Tidak dapat dipungkiri, partisipasi 
masyarakat dalam pengembangan ekowisata telah menawarkan sejumlah keuntungan ekonomi yang sebagian besar di bidang pengembangan infrastruktur kepada komunitas lokal (Mensah, 2017). Potensi pengembangan ekowisata bertujuan untuk mengangkat nama desa, menjaga dan melestarikan lingkungan, sampai untuk menciptakan lapangan kerja untuk masyarakat sehingga meminimalisir kemiskinan dan meningkatkan perekonomian masyarakat.

Masyarakat yang aktif dan ikut andil dalam pengembangan hutan mangrove bisa mendapat manfaat yang besar pula sesuai dengan usaha yang telah mereka lakukan, selain untuk meningkatkan wisatawan untuk berkunjung ke Siak. Adanya ekowisata hutan mangrove ini juga menambah tempat wisata alternatif yang bisa dikunjungi di Kabupaten Siak, sehingga tidak hanya fokus di Istana Siak Sri Indrapura saja.

Branding tujuan menciptakan proposisi tujuan yang unik. Ini adalah proses yang digunakan untuk mengembangkan identitas dan kepribadian unik yang berbeda dari semua tujuan kompetitif. Merek dapat diperbarui untuk mengikuti perkembangan zaman dan selera pelanggan (Achieng et al., 2014). Suatu tempat wisata apabila sudah banyak dikenal oleh masyarakat, maka masyarakat akan penasaran untuk mengunjungi tempat-tempat tersebut. Melihat apakah tempat tersebut sama dengan yang diinformasikan, dan apa saja yang telah disuguhkan dan dapat dinikmati untuk dilihat ataupun memiliki manfaat, baik dalam bidang pengetahuan ataupun yang lainnya. Aris

Dharma mengatakan:

"Pasti ada dampak yang diberikan dari setiap program-program atau kegiatankegiatan walaupun tidak besar, tetap saja ada dampaknya. Begitula dengan pengembangan ekowisata hutan mangrove ini. Dampakutamanyaadalahmeningkatkan jumlah pengunjung yang datang ke Siak. Karena dengan banyaknya destinasi tempat wisata yang di tawarkan maka akan banyak pula wisatawan yang akan berkunjung." (Wawancara, 28 Agustus 2019)

Segala usaha dilakukan oleh pemerintah dan masyarakat pengelola hutan mangrove untuk menarik minat wisatawan mengunjungi ekowisata hutan mangrove, dan itu membuahkan hasil yang cukup baik, karena jumlah pengunjung pun makin bertambah setiap waktu. Berikut yang disampaikan oleh Setiono. "Untuk pengunjung sendiri Alhamdulillah yang pada awalnya dari nol atau tidak ada yang mengunjungi, pada bulan September ini sudah ada sekitar 6000 pengunjung yang sudah terdaftar selama satu tahun ini. Tetapi jumlah pengunjung tersebut hanya yang dari luar daerah desa ini, tidak termasuk masyarakat setempat tidak dimasukkan kedalam buku tamu, karena kalo mereka dimasukkan maka akan lebih banyak dan tidak bisa menginputnya. Sehingga yang mengisi bukutamu hanya pengunjung yang datang dari luar daerah saja," (Wawancara, 12 September 2019)

Berdasarkan data yang didapat dari Dinas 
Tabel 1 Daftar Jumlah Kunjungan Wisatawan Ekowisata Hutan Mangrove di Kabupaten Siak Tahun 20182019

\begin{tabular}{ccccc}
\hline No & Objek Wisata & \multicolumn{2}{c}{ Jumlah Pengunjung } & Total \\
\hline & & 2018 & 2019 & \\
1 & Ekowisata Mengkapan & 5877 & 6366 & 12.243 \\
2 & Ekowisata Rawajaya & 4490 & 5878 & 10.368 \\
\hline
\end{tabular}

Sumber: Hasil Penelitian, 2019

Pariwisata Kabupaten Siak, jumlah kunjungan wisatawan kian bertambah dan dapat dilihat pada tabel 1 .

Peningkatan pada jumlah wisatawan menandakan adanya ketertarikan dari pihak eksternal selaku wisatawan nusantara ataupun wisatawan mancanegara untuk mengunjungi destinasi ekowisata mangrove. Pada aspek proses destination branding, peran terbesar yang kemudian dapat membentuk identitas destinasi wisata adalah persepsi dari khalayak yang juga merupakan calon wisatawan potensial bagi suatu tempat (Trisakti \& Alifahmi, 2018). Jika melihat pola peningkatan pengunjung dari tahun ke tahun, bisa diasumsikan bahwa persepsi khalayak terhadap destinasi ekowisata mangrove di Siak menunjukkan respon yang positif.

Pokdarwis dan pemerintah kabupaten Siak telah melakukan beberapa upaya dalam mengembangkan ekowisata hutan mangrove, mulai dari branding atau promosi yang dijadikan satu paket dengan wisata Siak lainnya, kemudian dilakukan pemeliharaan untuk tempat-tempat wisata yang ada di Siak. Terdapat beberapa upaya dari Dinas Pariwisata yang telah dilakukan yakni dengan meningkatkan kualitas sumber daya manusianya terlebih dahulu. Eka Susanti menjelaskan seperti dalam kutipan wawancara di bawah ini.

"Pertama meningkatkan sumber daya manusia (SDM) bagi para pengelola ekowisata hutan mangrove. Itu yang terpenting. Selain itu, menambahkan daya tarik seperti tempat-tempat istirahat pengunjung, tempat memancing dan lainlainnya. Kemudian memperbaiki jalan dengan bantuan pihak ketiga serta membuat wc umum dan penerangan."(Wawancara, 12 September 2019)

Kabid Pemasaran Pariwisata Basriansyah menambahkan bahwa Usaha yang dilakukan pemerintah pada tahap awal yakni dengan memfasilitasi masyarakat yang mengelolanya yaitu Pokdarwis. Kegiatan yang dilakukan berupa partisipasi Pokdarwis pada diklatdiklat atau pelatihan yang berhubungan dengan pariwisata, baik dalam segi pengelolaan, pengembangan, ataupun pemeliharaan, agar wawasan mereka bertambah tentang pariwisata dan dapat mengembangkan wisata dengan baik. Pemerintah kabupaten Siak juga memberikan 
reward atau penghargaan bagi Pokdarwis yang aktif mengikuti kegiatan tersebut guna memotivasi untuk lebih kreatif dan giat lagi dalam mengembangkan wisata-wisata yang ada. Menanggapi hal tersebut, Setiono menjelaskan bahwa dalam proses pelaksanaannya Pokdarwis telah mempraktikkan berbagai ilmu yang didapat dari pelatihan-pelatihan pariwisata.

"Sebagai hasil pelatihan pariwisata, kami mencoba membuat beragam kuliner seperti sirup, dodol, atau sovenir seperti gasing yang terbuat dari kulit rotan dan siput, kemudian menjual bibit apabila ada orang yang berminta untuk membelinya. Kami juga terus menambahkan trek jalan dalam hutan mangrove agar bisa dinikmati oleh pengunjung." (Wawancara, 12 September 2019)

Setelah masyarakat lokal dan pemiliknya berhasil memelihara kesadaran, pola pikir ekowisata mereka, dan diberikan pendidikan dan pelatihan untuk meningkatkan rasionalitas dan keterampilan mereka-baik itu pengemasan, rencana perjalanan, dan biaya- melalui program peningkatan kapasitas, mereka akan siap menjadi yang terbaik (Ik et al., 2018). Dampak yang timbul dari pengembangan ekowisata hutan mangrove dirasakan oleh masyarakat yang ada di sekitar lingkungan ekowisata hutan mangrove. Hal pertama yang akan didapat oleh masyarakat yang berada di sekitar tempat wisata tersebut adalah perputaran ekonomi. Masyarakat bisa mengambil keuntungan dengan berjualan di sekitar tempat wisata. Setiono turut menjelaskan bahwa respon masyarakat pun beragam.

"Alhamdulillah dampak dari berjalannya destinasi mangrove ini terlihat dari masyarakat ada yang berjualan disekitar hutan mangrove seperti berjualan nasi, jual minuman, jagung bakar, dan lain sebagainya. Tidak jauh dari ekowisata hutan mangrove juga sudah menyediakan home stay untuk para wisatawan yang mungkin ingin menginap atau bermalam, karena letak ekowisata hutan mangrove lumayan jauh dari kota Siak." (Wawancara, 12 September 2019)

Meskipun ekowisata sering kali dikaitkan dengan dampak ekonomi yang ditimbulkan, namun beberapa penelitian menunjukkan bahwa terdapat kepentingan yang berbeda dan saling bertentangan di tingkat global, nasional dan lokal (Byczek, 2011). Seperti halnya di Kabupaten Siak, dimana penghasilan lebih besar dari segi hiburan di lokasi destinasi ekowisata (mulai dari gembok cinta, dan sarana foto lainnya). Hal ini berbeda dengan penelitian oleh (Lonn et al., 2018) yang mengemukakan bahwa penghasilan yang relatif lebih besar dihasilkan oleh ekowisata berdasarkan homestay.

Perbedaan tersebut dinilai wajar terjadi berdasarkan karakter dan kondisi di daerah masing-masing, namun ide utamanya jelas pada pemberdayaan masyarakat lokal. Istilah Community-based tourism atau yang biasa disebut dengan ekowisata berbasis masyarakat membawa dimensi sosial ini selangkah lebih maju. Konsep ini menjelaskan bentuk 
ekowisata di mana masyarakat lokal memiliki kontrol substansial tinggi, dan keterlibatan lebih dalam pengembangan dan pengelolaannya, dan sebagian besar manfaat tetap dalam masyarakat.

United Nations World Tourism Organization (UNWTO) melalui United Nations Environmental Program (UNEP) telah memberikan arahan yang jelas mengenai bagaimana karakteristik umum dari ekowisata, di antaranya: (1) melibatkan apresiasi tidak hanya dari alam, tetapi juga budaya asli yang berlaku di daerah alami, sebagai bagian dari pengalaman pengunjung; (2) berisi edukasi dan interpretasi sebagai bagian dari penawaran wisata; (3) umumnya, tetapi tidak secara eksklusif, diorganisasi untuk kelompokkelompok kecil oleh usaha kecil, khusus dan milik lokal (sambil mengakui bahwa pihak eksternal juga memasarkan dan mengoperasikan ekowisata; (4) meminimalkan dampak negatif terhadap lingkungan alam dan sosial budaya; (5) mendukung perlindungan kawasan alam dengan menghasilkan manfaat ekonomi bagi para pengelola kawasan alam; (6) menyediakan pendapatan alternatif dan pekerjaan bagi masyarakat lokal; dan; dan (7) meningkatkan kesadaran konservasi lokal dan pengunjung (World Tourism Organization, 2002).

Sementara definisi dan karakteristik umum perlu dipahami, yang lebih penting adalah kesesuaian dan kualitas tindakan, bukan apa sebutannya. Proses yang terlibat dalam ekowisata meliputi semua aspek perencanaan, pengembangan, pemasaran dan pengelolaan sumber daya dan fasilitas untuk bentuk pariwisata ini. Dalam praktik pemasaran atau promosi atas destinasi ekowisata mangrove, beberapa media yang digunakan diantaranya ialah media cetak, media sosial, dan media online.

Media cetak seperti koran lokal dan buletin pariwisata, media sosial seperti Facebook, YouTube, dan Instagram. Media online seperti portal berita online. Promosi yang dilakukan oleh Pokdarwis biasanya dengan mengunggah foto beberapa spot unik, ataupun kunjungan wisatawan dan pejabat daerah di akun pengelola ekowisata hutan mangrove.

Dari beberapa media yang digunakan, media sosial dinilai memiliki efek yang signifikan dalam upaya promosi kawasan destinasi mangrove. Di zaman disrupsi seperti sekarang ini, optimalisasi penggunaan media sosial dinilai cocok digunakan dan dapat memberikan efisiensi biaya promosi yang dikeluarkan Setiono turut menjelaskan bagaimana media sosial berdampak baik bagi destinasi ekowisata. "Banyak pengunjung yang tau dan datang berkunjung ke ekowisata hutan mangrove karna melihat posting-an di media sosial. Sebagian dari mereka yang berkunjung tau setelah melihat postingan yang ada di media sosial, sehingga menarik minat mereka untuk berkunjung dan melihat langsung suasana ekowisata hutan mangrove. Jadi posting-an foto yang ada di Facebook 
dan Instagram memberikan dampak besar dalam menarik minat masyarakat, karena media sosial banyak digunakan baik kalangan remaja maupun dewasa." (Wawancara Penelitian, 2019)

Selain itu, promosi yang dinilai efektif berasal dari pemasaran mulut ke mulut antar masyarakat. Dokumentasi dalam kawasan destinasi ekowisata biasanya direkam dalam bentuk video dan diunggahke YouTube, sehingga teman-teman wartawan ikut membantu dalam mempromosikan ekowisata hutan mangrove ini. Pokdarwis mengatakan bahwa cara tersebut terbukti bisa mendapatkan feedback lebih cepat dari para wisatawan ataupun calon wisatawan. Setiono selaku pengelola yang mem-posting informasi juga manambahkan.

"Alhamdulillah, setelah dipromosikan melalui berbagai media ini jadi banyak pengunjung yang sebelumnya belum tau jika ada ekowisata hutan mangrove di Siak menjadi tau dan penasaran ingin melihat bagaimana hutan mangrove di Siak, sehingga jika ingin melihat hutan mangrove mereka tidak perlu jauh-jauh lagi pergi ke Dumai, karena di Siak sendiri sudah memiliki hutan mangrove." (Wawancara Penelitian, 2019)

Penggunaan media baru dalam hal promosi telah dilakukan oleh Pokdarwis di Kabupaten Siak guna mengkomunikasikan informasi mengenai destinasi ekowisata mangrove. Seiring berkembangnya zaman dan teknologi, para wisatawan menjadi lebih cerdas dalam mencari kualitas dan nilai uang yang dihabiskan.
Wisatawan menjadi semakin sadar akan dampaknya terhadap lingkungan dan sebagai hasilnya, akan menuntut produk pariwisata yang lebih berkelanjutan (Mearns, 2015).

Produk pariwisata berkelanjutan yang dimaksudkan ialah pembangunan pariwisata yang secara ekologis memberikan manfaat yang layak secara ekonomi dan adil secara etika, serta memberikan manfaat sosial terhadap masyarakat. Kebutuhan wisatawan dapat dipenuhi dengan tetap memperhatikan kelestarian kehidupan sosial-budaya, dan memberi peluang bagi generasi muda sekarang dan yang akan datang untuk memanfaatkan dan mengembangkannya (Satria, 2009). Ekowisata bukanlah sekedar konsep sederhana sebagaimana banyak diucapkan banyak pihak. Gagasan ini termasuk kompleks, dimana harus melibatkan banyak komponen, prinsip, dan kriteria. Tanpa mengimplementasikan prinsip atau kriteria tersebut, maka sebuah aktivitas wisata alam tidak dapat dikategorikan sebagai ekowisata.

Contohnya ialah hutan mangrove yang menjadi sumber perhatian di wilayah pesisir. Hutan mangrove sebagai sumber daya alam hayati mempunyai keragaman potensi yang memberikan manfaat bagi kehidupan manusia. Pemanfaatan produk dan jasa telah memberikan tambahan pendapatan dan bahkan merupakan penghasilan utama dalam pemenuhan kebutuhan 
hidup masyarakat.

Upaya pengembangan kawasan destinasi ekowisata mangrove oleh Pokdarwis di Kabupaten Siak pada akhirnya banyak mengundang calon wisatawan untukberkunjung, dengan melalui proses dari perencanaan, pelaksanaan, promosi, dan pengelolaan tempat. Berdasarkan temuan di lapangan dan penelitian terkait, diidentifikasi bahwa posisi strategi pengembangan ekowisata di kawasan mangrove berada pada kuadran I. Hal ini dimaksudkan dengan penggunaan kekuatan internal untuk mengambil keuntungan dari peluang eksternal. Strategi yang dikembangkan adalah: (1) mengembangkan produk ekowisata minat khusus mangrove; (2) meningkatkan fasilitas dan sarana; (3) meningkatkan mutu sumber daya manusia yang kompeten; (4) membuat akun media sosial bagi ekowisata mangrove; dan (5) meningkatkan koordinasi dengan pemerintah daerah terkait dengan pengawasan terhadap kelestarian dan kebersihan kawasan mangrove (Karlina, 2015). Upaya-upaya tersebut menjadi bukti bahwa pengembangan pariwisata di wilayah yang tidak termasuk prioritas bagi Indonesia juga aktif dilakukan oleh masyarakat lokal.

Masalah pariwisata Indonesia adalah konsentrasi kegiatan yang tinggi di provinsiprovinsi yang paling maju, seperti Jakarta, Bali, Yogyakarta, dan beberapa tempat di Sumatera
Utara, Sulawesi Utara, dan Sulawesi Selatan. Fakta-fakta ini menunjukkan bahwa masih banyak provinsi lain yang memiliki sumber daya ekowisata dan budaya tradisional yang unik tetapi belum dimanfaatkan dengan baik. Objekobjek wisata, seperti wisata cagar budaya, kota kecil tradisional, kota-kota kecil dan kota-kota pantai dan kota-kota tepi laut, pemandangan alam dan flora dan fauna margasatwa tersebar di seluruh negeri (Butarbutar \& Soemarno, 2013).

Kegiatan rekreasi dan minat khusus yang sesuai, seperti jalan setapak, fotografi dan program konservasi partisipatif, juga dapat menjadi bagian dari ekowisata. Di beberapa lokasi, perburuan dan penangkapan ikan dapat dimasukkan sebagai kegiatan yang sesuai, asalkan mereka diteliti dan dikendalikan dengan cermat dalam rencana pengelolaan yang mendukung konservasi. Penggunaan berkelanjutan semacam ini bergantung pada pengetahuan lokal, memberikan pendapatan lokal yang signifikan, dan mendorong masyarakat untuk memberi nilai tinggi pada satwa liar, yang menghasilkan manfaat konservasi netto.

Pengembangan pariwisata merupakan suatu proses yang berkelanjutan menuju ke tataran nilai yang lebih tinggi dengan cara melakukan penyesuaian dan koreksi berdasar pada hasil monitoring dan evaluasi serta umpan balik implementasi rencana sebelumnya yang 
merupakan dasar kebijaksanaan dan merupakan misi yang harus dikembangkan. Dalam perencanaan serta pengembangan ekowisata, partisipasi dari berbagai lini yang membentuk sebagai sistem itu sendiri. Upaya ini berbanding lurus dengan perencanaan pembangunan daerah yang telah dirancang (Wahyudi, 2017).

Dalam pengembangan sektor ekowisata, terdapat dua aspek yang perlu diperhatikan yakni aspek destinasi dan aspek market (pasar). Dari segi destinasi, pengembangan ekowisata hendaknya memperlihatkan tingkatan budaya, sejarah, dan ekonomi dari tujuan wisata. Meskipun masih banyak pekerjaan rumah untuk memoles destinasi ekowisata tersebut, namun pengelola ataupun pemerintah daerah harus tanggap akan tren dan permintaan pasar yang ada. Secara aplikatif, konsep ekowisata lebih fokus pada wisatawan dalam jumlah kecil tetapi dalam banyak kasus, kontrol dan pemantauan daya dukung daerah sasaran seringkali sulit (Manu et al., 2012).

Dampak pariwisata bagi lingkungan dikemukakan oleh Otoritas Pengembangan Pariwisata Sri Lanka meliputi menipisnya sumber daya alam, polusi, erosi tanah, hilangnya habitat alami, peningkatan tekanan pada spesies yang terancam punah, dan kerentanan yang meningkat terhadap kebakaran hutan (Manu et al., 2012).

Dampak negatif dari pariwisata dapat terjadi ketika tingkat penggunaan pengunjung lebih besar dari kemampuan lingkungan untuk mengatasi penggunaan ini dalam batas yang dapat diterima perubahan. Konsep ekowisata yang berfokus pada melestarikan dan memanfaatkan alam dan budaya masyarakat jauh lebih ketat dibandingkan dengan hanya keberlanjutan. Keberadaan Kelompok Sadar Wisata (Pokdarwis) menjadi alat penggerak bagi masyarakat tempatan untuk turut mengembangkan sumber daya yang dimiliki oleh masing-masing desa dan destinasi.

Partisipasi masyarakat lokal dalam segala upaya ekowisata bukanlah konsep baru. Kata partisipasi menyiratkan bagaimana dan sejauh mana orang dapat berbagi pandangan mereka, mengambil bagian dalam suatu kegiatan, proyek, program, pengambilan keputusan, pembagian keuntungan dan isu-isu lain yang terkait dengan proses pembangunan pariwisata. Hal tersebut yang diwakili oleh adanya Pokdarwis.

Alasan terpenting masuknya penduduk lokal dalam ekowisata adalah keadilan, dengan mempertimbangkan konservasi kawasan melalui pengembangan ekowisata yang tentunya memerlukan pembatasan dalam penggunaan tradisional sumber daya lokal oleh penduduk.

Salah satu upaya untuk mempersiapkan sumber daya yang mumpuni yakni pengadaan pelatihan kepada anggota Pokdarwis. Pemerintah daerah melalui Dinas Pariwisata 
tengah gencar memberikan pelatihan mengenai wawasan tata kelola obyek wisata, inovasi, serta keterampilan promosi di media sosial agar mampu mendatangkan banyak pengunjung (Azzam, 2020). Selain itu, Pokdarwis harus memahami betul tugas-tugas melayani pengunjung di obyek wisata yang mereka kelola. Seperti ramah, selalu tersenyum, penguasaan lokasi, dan memandu wisatawan dengan baik.

Dalam aspek pengembangan ekowisata lainnya, kegiatan meliputi: (1) Perencanaan pengembangan ekowisata; (2) Pengembangan Sarana; (3) Pemeliharaan aset ekowisata; dan (4) Pemberdayaan ekonomi masyarakat (Hakim dkk., 2019). Filosofi dari ekowisata lebih penting, dibandingkan hanya sekadar 'menjual' destinasi wisata. Sesuai dengan regulasi yang telah ditetapkan pemerintah dalam Peraturan Menteri Dalam Negeri Nomor 33 Tahun 2009 tentang Pedoman Pengembangan Ekowisata di Daerah, terdapat beberapa poin yang disebutkan sebagai berikut: (1) kesesuaian antara jenis dan karakteristik ekowisata; (2) konservasi, yaitu melindungi, mengawetkan, dan memanfaatkan secara lestari sumber daya alam yang digunakan untuk ekowisata; (3) ekonomis, yaitu memberikan manfaat untuk masyarakat setempat dan menjadi penggerak pembangunan ekonomi di wilayahnya serta memastikan usaha ekowisata dapat berkelanjutan; (4) edukasi, yaitu mengandung unsur pendidikan untuk mengubah persepsi seseorang agar memiliki kepedulian, tanggung jawab, dan komitmen terhadap pelestarian lingkungan dan budaya; (5) memberikan kepuasan dan pengalaman kepada pengunjung; (6) partisipasi masyarakat, yaitu peran serta masyarakat dalam kegiatan perencanaan, pemanfaatan, dan pengendalian ekowisata dengan menghormati nilai-nilai sosial budaya dan keagamaan masyarakat di sekitar kawasan; dan (7) menampung kearifan lokal.

Ekowisata memang dapat memberi kontribusi pada pendapatan, menyediakan lebih banyak infrastruktur seperti jalan dan listrik, atau pendapatan langsung untuk proyek masyarakat seperti pembangunan sekolah dan klinik kesehatan di tingkat masyarakat, tetapi ini harus didefinisikan dan dinyatakan dengan jelas selama pertumbuhannya (Adeleke \& Nzama, 2013). Ekowisata dapat berkontribusi pada pemberdayaan psikologis masyarakat lokal dengan meningkatkan rasa harga diri dan dengan menumbuhkan kebanggaan atas budaya dan warisan alamnya. Hal ini terjadi karena ekowisata mengungkapkan kepada publik nilai komunitas tuan rumah dalam hal keindahan alam atau keunikan budaya.

Potensi yang dapat dikembangkan dalam branding suatu destinasi ekowisata ialah melalui potensi daerah tersebut dan potensi alamiah (Fikri \& Febriana, 2018). Potensi 
daerah meliputi sumber daya manusia mulai dari kemampuan berusaha, situs buatan, dan sebagainya. Sementara potensi alamiah berupa sumber daya yang berasal dari alam seperti hutan, bahari, atau destinasi lainnya. masyarakat lokal kemudian dapat mengembangkan suatu destinasi ekowisata dengan mengemas produk-produk wisata yang menarik dan berbentuk atraksi wisata ataupun fasilitas yang melengkapinya.

Aspeklainyangjugapentingialahpemangku kepentingan dalam upaya pengembangan destinasi ekowisata. Dalam konsep branding, masyarakat termasuk pemangku kepentingan (stakeholders) dalam menyukseskan kegiatan promosi. Pada branding destinasi, organisasi dan individu yang secara langsung atau tidak langsung terlibat dalam pembuatan, kegiatan, dan pengelolaan proyek ekowisata berbasis masyarakat disebut sebagai pemangku kepentingan. Instansi pemerintah, pusat penelitian, organisasi non-pemerintah, warga lokal, otoritas tradisional, dan pengunjung termasuk di antara organisasi tersebut.

\section{SIMPULAN}

Kawasan destinasi ekowisata mangrove di Kabupaten Siak meliputi beberapa lokasi, diantaranya: Ekowisata Mangrove Rawa Mekar Jaya, Ekowisata Mangrove Mengkapan, dan Ekowisata Mangrove Sungai Rawa. Dalam implementasinya di Kabupaten Siak, ekowisata berbasis masyarakat (CBET) telah dilakukan sejak dimulainya inisiasi dari masyarakat tempatan untuk mengembangkan daerah konservasi hutan mangrove menjadi suatu destinasi ekowisata yang memberikan dampak keberlanjutan bagi masyarakat lokal. Dampak yang didapat diantaranya ialah pemberdayaan ekonomi, pelestarian lingkungan serta peningkatan pariwisata daerah.

Peran kelompok sadar wisata (Pokdarwis) dalam upaya pengembangan Siak Hijau meliputi perencanaan, pelaksanaan serta pengawasan kawasan Ekowisata Mangrove yang ditunjukkan dengan aktifnya masyarakat tempatan dalam memanfaatkan sumber daya alam menjadi daya tarik wisata dan penghasilan tambahan bagi kehidupan masyarakat sehari-hari. Masyarakat mendapat pengetahuan baru dalam mengelola kawasan destinasi hutan mangrove melalui pelatihan-pelatihan mengenai pariwisata yang difasilitasi oleh pemerintah kabupaten Siak.

Hasil yang didapat dengan adanya pengembangan ekowisata hutan mangrove ini memberikan dampak positif untuk masyarakat sekitar, terutama meningkatkan perekonomian masyarakat, karena dengan adanya ekowisata di desa mereka bisa berjualan, menyediakan tempat parkir, homestay, dan juga untuk mengenalkan desa mereka, agar tidak menjadi desa yang tertinggal lagi. Pemerintah sendiri 
mendapatkan manfaat dengan meningkat jumlah kunjungan yang datang ke Siak dan khalayak luas lebih banyak yang mengetahui tentang program Siak Hijau.

Bentuk promosi dilakukan melalui komunikasi konvensional, yakni mulut ke mulut dan juga penggunaan media sosial sebagai sarana promosi melalui akun pribadi warga. Hal-hal yang harus diperhatikan seperti ketentuan pengunjung termasuk akses ke area alami dan warisan budaya, layanan pemandu dan interpretatif, akomodasi, katering, penjualan hasil bumi dan kerajinan, dan transportasi.

Penelitian lanjutan dibutuhkan untuk mengetahui bagaimana dampak langsung dan tidak langsung yang dirasakan oleh masyarakat tempatan dalam konteks community based ecotourism (CBET) dan pengembangan suatu kawasan destinasi ekowisata. Dalam praktiknya, dampak yang dimunculkan CBET memang erat kaitannya dengan perekonomian. Wujud keterlibatan masyarakat sekitar perlu ditingkatkan, tidak hanya pada proses pelaksanaan saja melainkan mulai dari perencanaan hingga pengambilan keputusan. Keterlibatan masyarakat lokal penting dalam pengembangan ekowisata dan melihat apakah konsep keberlanjutan sesuai dengan prinsip budaya tempatan dan tidak mengeksploitasi alam tanpa mengindahkan kestabilan alam yang ada.
Upaya pengembangan ekowisata, selain menawarkan pengalaman wisata yang positif, harus berkelanjutan secara ekonomi, ramah lingkungan, dan dapat diterima secara sosial jika ingin dipertahankan. Para pengunjung harus mendapatkan pengalaman yang berkesan selama mengunjungi destinasi tersebut, sehingga dapat menimbulkan efek mempengaruhi wisatawan lainnya.

Selain itu, dari aspek praktis dibutuhkan bentuk perpaduan promosi dalam bentuk word of mouth dan digital dengan penggunaan key opinion leader (KOL) atau influencer untuk mengkomunikasikan adanya ekowisata mangrove di Kabupaten Siak sehingga dapat menarik lebih banyak wisatawan yang akan berkunjung, mulai dari wisatawan nusantara maupun wisatawan mancanegara.

Untuk mengetahui kondisi dan kualitas dari destinasi wisata, perlu adanya suatu penilaian yang mampu mengetahui sejauh mana pengelolaan destinasi tersebut. Penilaian dapat dilakukan dengan objek penelitian berupa pelaku wisata, khususnya kelompok sadar wisata pada daerah yang menjadi fokus pengembangan ekowisata.

\section{DAFTAR PUSTAKA}

Achieng, D. O., O. Hayombe, P., \& G. Agong, S. (2014). Positioning ecotourism destinations in Kisumu County: cultural diversity perspective. IOSR Journal of Computer 
Engineering, 16(6), 16-26. https://doi. org/10.9790/0661-16631626

Adeleke, B. O., \& Nzama, T. (2013). Assessment of community participation in ecotourism and conservation at hhuhuwe-umfolozi Park, South Africa. Journal of Environment and Earth Science, 3(3), 12. https://www. iiste.org/Journals/index.php/JEES/article/ view/4771

Annesva, S. R. (2016). Mengenal mangrove Aceh Insight. https://acehinsight.wwf. id/2016/09/09/mengenal-mangrove/

Azzam, M.(2020).Pokdarwis Kabupaten Bekasi diberi pelatihan inovasi dan promosi. wartakota Travel. https://wartakotatravel. tribunnews.com/2020/09/18/pokdarwiskabupaten-bekasi-diberi-pelatihaninovasi-dan-promosi

Baharudin, A. (2011). Kebutuhan ruang terbuka hijau pada kawasan pusat Kota Jayapura. Jurnal Bumi Lestari, 11(2), 9.

Butarbutar, R., \& Soemarno, S. (2013). Environmental effects of ecotourism in Indonesia. Journal of Indonesian Tourism and Development Studies, 1(3), 97-107. https://doi.org/10.21776/ ub.jitode.2013.001.03.01

Byczek, C. (2011). Blessings for all? community-based ecotourism in bali between global, national, and local interests - a case studyblessings for all? communitybased ecotourism in Bali between global, national, and local interests - a case study. ASEAS - Österreichische Zeitschrift Für Südostasienwissenschaften. https://doi. org/10.4232/10.ASEAS-4.1-5

Creswell, J. W. (2007). Qualitative inquiry and research design: choosing among five approaches. SAGE Publications. https://books.google.co.id/ books?id=DetLkgQeTJgC
Dudovskiy, John. (2015). Qualitative data analysis. research-methodology. https:// research-methodology.net/researchmethods/data-analysis/qualitative-dataanalysis/

Febriansyah, F., Hartono, D., Negara, B. F. S., Renta, P. P., \& Sari, Y. P. (2018). Struktur komunitas hutan mangrove di Pulau Baai Kota Bengkulu. JURNAL ENGGANO, 3(1), 112-128. https://doi.org/10.31186/ jenggano.3.1.112-128

Fikri, M. A., \& Febriana, P. (2018). Branding Desa Kalanganyar sebagai ekowisata bahari di Kabupaten Sidoarjo. KANAL: Jurnal Ilmu Komunikasi, 5(1), 61. https:// doi.org/10.21070/kanal.v5i1.1461

Fiorello, A., \& Bo, D. (2012). Communitybased ecotourism to meet the new tourist's expectations: an exploratory study. Journal of Hospitality Marketing \& Management, 21(7), 758-778. https://doi.org/10.1080/19 368623.2012 .624293

Goodwin, H., \& Santilli, R. (2009). Communitybased tourism: A success? 37.

Hakim, N., Hayati, S., Lumbu, A. A., Rahmawati, N. I., \& Septiyana, L. (2019). Pemberdayaan kelompok sadar wisata (pokdarwis) dalam mengembangkan ekowisata Desa Gunung Rejo Kecamatan Way Ratai. 1(2), 20. https://e-journal. metrouniv.ac.id/index.php/JPM/article/ view/1760

Harwood, S. (2010). Planning for community based tourism in a remote location. Sustainability, 2(7), 1909-1923. https:// doi.org/10.3390/su2071909

Ik, M., H., Y., A, B., \& D, P. (2018). Local Indigenous branding: Bali ecological tourism village. International Journal of Scientific and Research Publications, 8(1), 8. 
Insch, A. (2011). Conceptualization and anatomy of green destination brands. International Journal of Culture, Tourism and Hospitality Research, 5(3), 282-290. https://doi. org/10.1108/17506181111156970

Karlina, E. (2015). Strategi pengembangan ekowisata mangrove di kawasan pantai Tanjung Bara, Kutai Timur, Kalimatan Timur. Jurnal Penelitian Hutan dan Konservasi Alam, 12(2), 191-208. https:// doi.org/10.20886/jphka.2015.12.2.191-208

Kementerian Perikanan dan Kelautan, A. (2019, Oktober). Zonasi Ekosistem hutan mangrove. https://kkp.go.id/djprl/ artikel/14410-zonasi-ekosistem-hutanmangrove

Lonn, P., Mizoue, N., Ota, T., Kajisa, T., \& Yoshida, S. (2018). Evaluating the Contribution of community-based ecotourism (cbet) to household income and livelihood changes: a case study of the chambok cbet program in cambodia. Ecological Economics, 151, 62-69. https:// doi.org/10.1016/j.ecolecon.2018.04.036

Manu, I., Kuuder, C.-J., \& Wuleka, W. (2012). Community-based ecotourism and livelihood enhancement in Sirigu, Ghana .pdf. International Journal of Humanities and Social Science, 2(8), 97.

Mearns, K. (2015). Applying sustainable tourism indicators to community-based ecotourism ventures in Southern Africa. Athens Journal of Tourism, 2(3), 179-194. https://doi.org/10.30958/ajt.2-3-4

Mensah, I. (2017). Benefits and challenges of community-based ecotourism in park-fringe communities: the case of mesomagor of kakum national park, Ghana. Tourism Review International, 21(1), 81-98. https://doi.org/10.3727/1544 $27217 \mathrm{X} 14866652018947$
Mohajan, H. K. (2018). Qualitative research methodology in social sciences and related subjects. Journal of Economic Development, Environment and People, 7(1), 23. https://doi.org/10.26458/jedep. v7i1.571

Pesona Siak-The Official Guide of Siak Regency. (2019). http://pesonasiak.id/

Prasetyo, A., Santoso, N., \& Prasetyo, L. B. (2017). Kepekaan lingkungan ekosistem mangrove terhadap tumpahan minyak di Kecamatan Ujung Pangkah, Gresik. Jurnal Penelitian Hutan dan Konservasi Alam, 14(2), 91-98. https://ejournal.forda-mof. org/ejournal-litbang/index.php/JPHKA/ article/view/3036

Punch, K. F. (2013). Introduction to social research: quantitative and qualitative approaches. SAGE Publications. https://books.google.co.id/ books?id=G2fOAgAAQBAJ

Purbaningrum, C. W. D. (2018). Communitybased ecotourism as an alternative to the development of vocational tourism. TAMAN VOKASI, 6(2), 170. https://doi. org/10.30738/jtv.v6i2.4150

Putri, N. E., Hakim, N., \& Yamin, M. (2016). Ecologicall footprint and biocapacity analysis for flooding prevention in South Sumatera. Jurnal Mimbar, 32(1), 58-64.

Rijal, S. (2008). Kebutuhan ruang terbuka hijau di Kota Makassar Tahun 2017. Jurnal Hutan Dan Masyarakat, 1, 13.

Satria, D. (2009). Strategi pengembangan ekowisata mangrove di kawasan pantai Tanjung Bara, Kutai Timur, Kalimatan Timur. Journal of Indonesian Applied Economics, 3(1), 1-2009. https://doi. org/10.21776/ub.jiae.2009.003.01.5

Siak, S., \& Siak, P. (2019). Peta jalan (roadmap) siak kabupaten Hijau - Jikalahari. http:// 
jikalahari.or.id/kabar/peta-jalan-roadmapsiak-kabupaten-hijau/

Trisakti, F. A., \& Alifahmi, H. (2018). Destination brand storytelling: analisis naratif video the journey to a wonderful world kementerian pariwisata. Jurnal Komunikasi Indonesia, 7(1), 73-86. https:// doi.org/10.7454/jki.v7i1.9692

Wahyudi, I. (2017). Konsep pengembangan pariwisata. INSPIRE Consulting. http:// cvinspireconsulting.com/konseppengembangan-pariwisata/

What Is Ecotourism. (2018). The international ecotourism society. https://ecotourism.org/ what-is-ecotourism/

Widana, I. (2019, Juni 3). Berhasil menjadikan siak hijau, bupati alfedri berbicara di forum dunia. GoRiau.com. https://www.goriau. com/berita/baca/berhasil-menjadikan-siak- hijau-bupati-alfedri-berbicara-di-forumdunia.html

World Tourism Organization, U. N. (2002). The world ecotourism summit final report (world). https://www.e-unwto.org/doi/ pdf/10.18111/9789284405503

Yaman, A. R., \& Mohd, A. (2004). Communitybased ecotourism- a new proposition for sustainable development and environmental conservation in Malaysia.pdf. Journal of Applied Sciences, 4(4).

Zul, Z. (2017). Bupati Syamsuar launching kawasan eco tourism hutan mangrove sungai rawa-berita Riau terkini. http:// riaugreen.com/view/Siak/24193/BupatiSyamsuar-Launching-Kawasan-EcoTourism-Hutan-Mangrove-Sungai-Rawa. html\#.XkoO3RMzZE4 